\title{
PSYCHOLOGICAL EMPOWERMENT IN THE SOUTH AFRICAN MILITARY: THE GENERALISABILITY OF MENON'S SCALE
}

\author{
ELIZE KOTZE \\ elize@ma2.sun.ac.za \\ Faculty of Military Science \\ Stellenbosch University \\ SANJAY T MENON \\ smenon@pilot.isus.edu \\ Department of Management and Marketing \\ Louisiana State University Shreveport, USA \\ BARRY VOS \\ bvos@webmail.co.za \\ Centre for Effect Analysis \\ SA Department of Defence \\ Pretoria
}

\begin{abstract}
The aim of this study was to investigate the factorial validity and internal consistency of the Menon Scale for Psychological Empowerment, developed in the United States and Canada and tested in Australia and Greece, in the South African National Defence Force (SANDF). The 2231 participants in the study represented the gender and racial distribution of the military population. The South African data initially yielded a two-factor structure. A forced three-factor structure rendered acceptable alpha coefficients, but did not resemble the theoretically expected factors. The forced factor analyses were repeated for Africans, Asians and Coloureds, and Whites separately. Results for the first two groups kept the original structure, whereas the factor structure for the white participants resembled the theoretically hypothesised factors. The forced three-factor structures rendered very high internal consistencies for the total scale, but one factor for both the African and the Asian and Coloured groups showed unsatisfactory reliability, suggesting a single underlying empowerment factor. This was confirmed by high correlations between subscales. Menon's model seemingly fits the South African data slightly better for the white participants than for their non-white counterparts. The scale thus needs to be revised for the different cultural groups.
\end{abstract}

Key words:

Psychological empowerment; South African military

\section{Previous Presentation}

A shorter version of this paper was presented at the Tenth $\mathrm{Bi}$ annual Conference of the International Society for the Study of Work and Organisational Values (ISSWOV) in Tallinn, Estonia, 25-29 June 2006,

Prior to 1990 empowerment was mainly studied from a sociological perspective, being thought of as the granting of power by the relatively powerful to the less powerful. In an organisational context this would involve "moving decision-making authority down the organisational hierarchy and granting employees the ability to significantly affect organisational outcomes" (Menon, 2001, p156). This approach, which focuses on the transfer of power and authority, has been labeled the structural approach (Boudrias, Gaudreau \& Lashinger, 2004). Structural empowerment can be enhanced in various ways, which Spreitzer (1996) identified as socio-political support, access to information, a wide span of control, low role ambiguity, and a participative organisational climate - all of which are national or organisational strategies to empower citizens or employees.

The sociological approach to empowerment emphasises the act of granting power to an employee. It is, however, also important to determine whether the act of empowerment leaves the individual with the subjective feeling of being empowered, as there is no guarantee that organisational practices will necessarily create a subjective feeling of empowerment within the individual (Conger \& Kanungo, 1988). This subjective experience of empowerment is defined as psychological empowerment and the focus is on the individual. Menon (2001) cautions, however, that the sociological and psychological approaches are not mutually exclusive, but rather ensure a comprehensive picture of the phenomenon.

\section{Psychological empowerment}

Conger and Kanungo (1988) encouraged the psychological approach to empowerment and stated that empowerment pertains to organisations that create the opportunity for the development of feelings of self-efficacy and remove conditions that contribute to powerlessness. Shortly after Conger and Kanungo's publication followed the work of Thomas and Velthouse (1990) who viewed power as energy and linked it with the intrinsic motivation of workers. Based on Thomas and Velthouse's cognitive interpretation of empowerment (Kraimer, Seibert \& Liden, 1999), Spreitzer (1995) developed a model consisting of four components, namely meaning (of work goal), competence, self-determination, and impact (on work outcomes). Menon (2001), in turn, pointed out several concerns about the diverse approaches to empowerment and redefined psychological empowerment as "a cognitive state characterised by a sense of control, competence and goal internalisation (p161). Perceived control reflects beliefs about autonomy, peceived competence refers to a sense of efficacy and feelings of personal capability, and goal internalisation represents the energising power of, for instance, an organisation's vision for the future, and the individuals' association with such a vision or goal.

Empowerment in the South African context

In South Africa much emphasis has been placed by both the State and employers in the private sector on the "empowerment" of employees. Granting political power to all citizens in 1994 can be considered as the watershed in the process of national empowerment. Later on legislation regarding equal opportunities, affirmative action and skills development have continued to stimulate the transfer of power to the previously powerless. More recently "Black Economic Empowerment" (BEE) has become a national priority and forms the headline of many reports on the business pages of national newspapers. State and private organisations alike opted for a more participative management 
style. However, Khosa (2001) is of the opinion that even after introducing new corrective policy measures in South Africa, discrimination and poverty, and consequently powerlessness, continue to exist. The question whether employees in the new dispensation indeed feel empowered (experience psychological empowerment) remains largely unanswered.

\section{Psychological empowerment and the military}

The military has traditionally been viewed as an organisation where employees are expected to follow orders. The argument is that a soldier acting independently from his or her superiors, especially during wartime, is a liability (Laschinger, Finegan, Shamian \& Wilk, 2004). In this sense the military can thus be perceived as a "disempowering" institution. This perception is confirmed by Klidas (quoted in Dimitriades, 2005) who states that large power distance organisations, like the military, will not be really susceptible for empowerment actions. In such organisations decision-making is usually centralised within the higher ranks, and is not easily moved down the organisational hierarchy. Furthermore the military operates according to very precise procedures and rules to minimise uncertainty and ambiguity or misunderstanding between military leaders and their subordinates. Klidas argues that the empowerment doctrine supports an environment of low formalisation with few policy manuals or detailed procedures and rules. This will supposedly give employees the flexibility to exercise their own discretion and initiative.

Despite the traditional perception that the military is unable or unwilling to empower subordinates, the South African National Defence Force (SANDF) had to adapt to a much more ambiguous environment due to the societal changes and challenges of the dispensation after 1994. This necessitated the implementation of an integrated command and leadership approach, and transformational leadership theory is presently utilised as a basis for leadership development programmes (Department of Defence, 2000). Followers of transformational leaders are expected to identify with their leaders and believe that they can have an impact on the organisation (Avolio, Zhu, Koh \& Bhatia, 2004), which, in turn, enhances psychological empowerment. One way of determining the success of the SANDF's transformational leadership training programmes is to evaluate to what extent subordinates experience psychological empowerment. For this purpose a suitable instrument to measure the impact of psychological empowerment in the SANDF becomes indispensable. The general aim of this study is to evaluate one such instrument, namely Menon's Psychological Empowerment Scale, for its applicability in the SANDF.

\section{The measurement of psychological empowerment}

Menon and Hartmann (2002) state that the measurement of empowerment has been dominated by Spreitzer's (1995) model reflecting the components of meaning, competence, self-determination, and impact. This notion is supported by Boudrias et al. (2004) who reported that Spreitzer's Psychological Empowerment Questionnaire has been used in more than 25 empirical studies. Yet, a number of concerns have been raised about the instrument, inter alia about the data set used for the research and the intercorrelations between the subscales (Menon \& Hartmann, 2002). More recently Menon (2001) developed a measuring instrument reflecting the three components described in his model. His original study included French and English speaking Canadians, suggesting that the scale has cross-cultural generalisability. This was later confirmed in studies in Australia (Menon \& Hartmann, 2002) and Greece (Dimitriades, 2005).

Although the cross-cultural applicability of the scale was confirmed in Western societies, Matsumoto and Juang (2004) maintained that different cultural groups have different perceptions, and these differences could influence the interpretation of psychological constructs. Consequently items that measure the concept of psychological empowerment could be interpreted differently by members of different cultural groups. It is therefore imperative that the psychometric qualities of measuring instruments developed in the West should be validated for African settings.

Research on the reliability and validity of psychometric instruments is of particular importance in the South African context, as their application in a culturally heterogeneous society has often been a controversial issue. Previously test development and validation has been done by the Human Sciences Research Council. This institution has, however, been rationalised due to political changes, and now gives priority to national research needs. Consequently research in the psychometric area is now left to be done by researchers at South African universities (Foxcroft \& Roodt, 2001).

The applicability of the Menon scale has been tested in South Africa in a preliminary non-random sample in the South African military and acceptable reliabilities were found (Menon $\&$ Kotze, 2004). The factor structure of the questionnaire has, however, not yet been investigated in the culturally diverse SANDF population. This study seeks to address the gap in the literature in two ways. Firstly, the aim of the study is to determine whether the same three factors, namely perceived control, competence and goal internalisation as identified by Menon (2001) and confirmed by Menon \& Hartmann (2002) in Autralia and Dimitriades (2005) in Greece, can also apply in a culturally heterogeneous institution such as the SANDF. Secondly, the aim of the study is to determine the reliability of the scale in a larger representative sample from the SANDF than the one referred to above.

\section{RESEARCH DESIGN}

\section{Research approach}

The questionnaire items used for this study were included in a larger survey conducted by the SANDF. The military population was divided into nine strata according to arms of service and divisions. Members in each stratum were numbered according to rank and alphabetically per military unit, and 10113 personnel were selected randomly to complete one of two questionnaires. Of the $50 \%$ selected to complete the questionnaire for this research, a total of 2232 usable questionnaires were returned. There were $1815(81,4 \%)$ male respondents and 416 female respondents distributed across various ranks. The gender distribution of the sample corresponds to that of the military population as reported in the Department of Defence's (DoD) Annual Report for 2003-2004 which indicates that 21,7\% of the SANDF's members are women. With regard to the racial distribution of the sample, $58.8 \%$ (1313) of the respondents were African, 25\% (557) were White, and the rest Asian or Coloured. This distribution is consistent with the DoD's guidelines of $64,68 \%$ Blacks and $24,35 \%$ Whites (http//:www. mil.za/Artciles\&Papers/Annualreports/annualreport2003_2004/ AnnualReport04.pdf). Due to the small size of the Asian group, this group was combined with the Coloured participants.

\section{Measuring instrument}

Psychological empowerment was assessed with Menon's (Menon, 2001) 15-item instrument, comprising three five-item scales, which reflect perceived control (e.g. "I can influence the way work is done in my unit/base/ship"), perceived competence (e.g. "I have the skills and abilities to do my job well") and goal intenalisation ( e.g. "I am inspired by the goals of the organisation"). Respondents had to indicate their degree of agreement on a seven-point Likert scale $(1=$ strongly disagree; 7 = strongly agree). Menon (2001) reported alpha reliability coefficients of $0,83,0,80$ and 0,88 for the three scales respectively. The same study also provided strong evidence of construct validity of the scale. 
Statistical analysis

Principal components analyses with varimax rotation of the original 15 items in the Menon Empowerment Scale (2001) were done for the total group as well as for the different racial groups separately. In the first instance the number of factors to be extracted was not specified. Secondly, it was specified that three factors be extracted, as was theoretically expected. In the third instance reliability coefficients were determined for the total scale and also for each factor separately. In the last instance the inter-correlations between the three sub-scales were calculated.

\section{RESULTS}

The findings for this study will be reported in two sections according to the goal formulation, namely, firstly, the results of the factor analyses, and, secondly, the reliability coefficients and inter- sub-scale correlations.

\section{Factor analyses}

Principal components analysis, with varimax rotation of the original 15 items in the Menon Empowerment Scale (2001) yielded a two-factor structure which explained $53,166 \%$ variance. The factors show eigen values of 6,749 and 1,226 respectively. The factor analysis was then repeated forcing it to identify three factors as expected from previous research. The first two factors have the same eigen values with the third eigen value $=0,955$, In the last case $59,53 \%$ variance is explained. Relatively high crossloadings are observed for two items in both the 2- and 3-factor results of which item 7 appears in both. The various items and their factor loadings are reflected in Tables 1 and 2. The identified factor items are further compared to the factor items established by Menon (2001) and Menon and Hartmann (2002).

TABLE 1

FACTOR ANALYSIS: UNSPECIFIED NUMBER OF FACTORS AND COMPARED TO PREVIOUS FINDINGS

\begin{tabular}{|c|c|c|c|}
\hline & \multicolumn{2}{|c|}{ Component } & \multirow{2}{*}{$\begin{array}{l}\text { Menon(2001) and } \\
\text { Menon \& } \\
\text { Hartmann (2002) }\end{array}$} \\
\hline & 1 & 2 & \\
\hline 22. I can do my work efficiently. & 0,794 & 0,097 & Competence factor \\
\hline $\begin{array}{l}\text { 23. I am keen on our doing well as } \\
\text { an organisation. }\end{array}$ & 0,754 & 0,198 & $\begin{array}{l}\text { Goal internalisation } \\
\text { factor }\end{array}$ \\
\hline $\begin{array}{l}\text { 12. I have the capabilities required } \\
\text { to do my job well. }\end{array}$ & 0,745 & 0,171 & Competence factor \\
\hline $\begin{array}{l}\text { 13. I am enthusiastic about the } \\
\text { contribution my work makes to } \\
\text { the organisation. }\end{array}$ & 0,740 & 0,292 & $\begin{array}{l}\text { Goal internalisation } \\
\text { factor }\end{array}$ \\
\hline $\begin{array}{l}\text { 21. Important responsibilities are } \\
\text { part of my job. }\end{array}$ & 0,724 & 0,199 & $\begin{array}{l}\text { Perceived control } \\
\text { factor }\end{array}$ \\
\hline $\begin{array}{l}\text { 17. I can handle the challenges I face } \\
\text { at work. }\end{array}$ & 0,687 & 0,251 & Competence factor \\
\hline $\begin{array}{l}\text { 18. I am inspired by what we } \\
\text { are trying to achieve as an } \\
\text { organisation. }\end{array}$ & 0,638 & 0,332 & $\begin{array}{l}\text { Goal internalisation } \\
\text { factor }\end{array}$ \\
\hline $\begin{array}{l}\text { 8. I am enthusiastic about working } \\
\text { towards the organisation's } \\
\text { objectives. }\end{array}$ & 0,624 & 0,391 & $\begin{array}{l}\text { Goal internalisation } \\
\text { factor }\end{array}$ \\
\hline $\begin{array}{l}\text { 2. I have the skills and abilities to } \\
\text { do my job well. }\end{array}$ & 0,513 & 0,333 & Competence factor \\
\hline $\begin{array}{l}\text { 11. I have the authority to work } \\
\text { effectively. }\end{array}$ & 0,502 & 0,487 & $\begin{array}{l}\text { Perceived control } \\
\text { factor }\end{array}$ \\
\hline $\begin{array}{l}\text { 7. I have the competence to work } \\
\text { effectively. }\end{array}$ & 0,491 & 0,481 & Competence factor \\
\hline $\begin{array}{l}\text { 6, I have the authority to make } \\
\text { decisions at work. }\end{array}$ & 0,089 & 0,777 & $\begin{array}{l}\text { Perceived control } \\
\text { factor }\end{array}$ \\
\hline $\begin{array}{l}\text { 1. I can influence the way work is } \\
\text { done in my unit/base/ship. }\end{array}$ & 0,192 & 0,681 & $\begin{array}{l}\text { Perceived control } \\
\text { factor }\end{array}$ \\
\hline $\begin{array}{l}\text { 16, I can influence decisions taken } \\
\text { in my department. }\end{array}$ & 0,186 & 0,638 & $\begin{array}{l}\text { Perceived control } \\
\text { factor }\end{array}$ \\
\hline $\begin{array}{l}\text { 3. I am inspired by the goals of the } \\
\text { organisation. }\end{array}$ & 0,402 & 0,549 & $\begin{array}{l}\text { Goal internalisation } \\
\text { factor }\end{array}$ \\
\hline
\end{tabular}

Extraction Method: Principal Component Analysis.

Rotation Method: Varimax with Kaiser Normalization.

Rotation converged in 3 iterations.
TABLE 2

FACTOR ANALYSIS: THREE FACTORS SPECIFIED AND COMPARED TO PREVIOUS FINDINGS

\begin{tabular}{|c|c|c|c|c|}
\hline & \multicolumn{3}{|c|}{ Component } & \multirow{2}{*}{$\begin{array}{c}\text { Menon (2001) } \\
\text { and Menon } \\
\text { \& Hartmann } \\
(2002)\end{array}$} \\
\hline & 1 & 2 & 3 & \\
\hline 22. I can do my work efficiently. & 0,798 & 0,128 & 0,108 & $\begin{array}{l}\text { Competence } \\
\text { factor }\end{array}$ \\
\hline $\begin{array}{l}\text { 21. Important responsibilities are } \\
\text { part of my job. }\end{array}$ & 0,743 & 0,106 & 0,244 & $\begin{array}{l}\text { Perceived } \\
\text { control factor }\end{array}$ \\
\hline $\begin{array}{l}\text { 23. I am keen on our doing well } \\
\text { as an organisation. }\end{array}$ & 0,725 & 0,260 & 0,132 & $\begin{array}{l}\text { Goal } \\
\text { internalisation } \\
\text { factor }\end{array}$ \\
\hline $\begin{array}{l}\text { 12. I have the capabilities } \\
\text { required to do my job well. }\end{array}$ & 0,711 & 0,264 & 0,095 & $\begin{array}{l}\text { Competence } \\
\text { factor }\end{array}$ \\
\hline $\begin{array}{l}\text { 13. I am enthusiastic about the } \\
\text { contribution my work makes } \\
\text { to the organisation. }\end{array}$ & 0,693 & 0,343 & 0,185 & $\begin{array}{l}\text { Goal } \\
\text { internalisation } \\
\text { factor }\end{array}$ \\
\hline $\begin{array}{l}\text { 17. I can handle the challenges I } \\
\text { face at work. }\end{array}$ & 0,671 & 0,226 & 0,215 & $\begin{array}{l}\text { Competence } \\
\text { factor }\end{array}$ \\
\hline $\begin{array}{l}\text { 18. I am inspired by what we } \\
\text { are trying to achieve as an } \\
\text { organisation. }\end{array}$ & 0,564 & 0,429 & 0,161 & $\begin{array}{l}\text { Goal } \\
\text { internalisation } \\
\text { factor }\end{array}$ \\
\hline $\begin{array}{l}\text { 11. I have the authority to work } \\
\text { effectively. }\end{array}$ & 0,506 & 0,213 & 0,498 & $\begin{array}{l}\text { Perceived } \\
\text { control factor }\end{array}$ \\
\hline $\begin{array}{l}\text { 3. I am inspired by the goals of } \\
\text { the organisation. }\end{array}$ & 0,225 & 0,793 & 0,135 & $\begin{array}{l}\text { Goal } \\
\text { internalisation } \\
\text { factor }\end{array}$ \\
\hline $\begin{array}{l}\text { 1. I can influence the way work } \\
\text { is done in my unit/base/ship. }\end{array}$ & 0,060 & 0,661 & 0,375 & $\begin{array}{l}\text { Perceived } \\
\text { control factor }\end{array}$ \\
\hline $\begin{array}{l}\text { 2. I have the skills and abilities } \\
\text { to do my job well. }\end{array}$ & 0,383 & 0,587 & 0,031 & $\begin{array}{l}\text { Competence } \\
\text { factor }\end{array}$ \\
\hline $\begin{array}{l}\text { 8. I am enthusiastic about } \\
\text { working towards the } \\
\text { organisation's objectives. }\end{array}$ & 0,506 & 0,585 & 0,116 & $\begin{array}{l}\text { Goal } \\
\text { internalisation } \\
\text { factor }\end{array}$ \\
\hline $\begin{array}{l}\text { 7. I have the competence to } \\
\text { work effectively. }\end{array}$ & 0,424 & 0,432 & 0,328 & $\begin{array}{l}\text { Competence } \\
\text { factor }\end{array}$ \\
\hline $\begin{array}{l}\text { 6, I have the authority to make } \\
\text { decisions at work. }\end{array}$ & 0,090 & 0,257 & 0,783 & $\begin{array}{l}\text { Perceived } \\
\text { control factor }\end{array}$ \\
\hline $\begin{array}{l}\text { 16, I can influence decisions } \\
\text { taken in my department. }\end{array}$ & 0,239 & 0,062 & 0,765 & $\begin{array}{l}\text { Perceived } \\
\text { control factor }\end{array}$ \\
\hline
\end{tabular}

Extraction Method: Principal Component Analysis.

Rotation Method: Varimax with Kaiser Normalization.

Rotation converged in 6 iterations.

From the above tables it can be deducted that neither the unspecified nor the specified number of factors approach give a factor structure comparable to those of Menon (2001), Menon and Hartmann (2002) or Dimitriades (2005). As previous research suggested that ethnic group plays an important role in psychological empowerment (Kotze, Khashane \& Mthembu, in press), the forced factor analyses were repeated for Africans, Asians and Coloureds, and Whites separately. The results are given in Tables 3 to 5, For the African group the three factors explained $60.25 \%$ of the variance (eigen values $=4,51,2,71$ and 1,82 respectively), for the Coloured and Asian group 57,57\% variance is explained (eigen values $=6,05,1,41$ and 1,18 respectively) and for the White group $63,83 \%$ variance is explained (eigen values = $6,68,1,60$ and 1,40 respectively). 
TABLE 3

FACtor anAlysis results for three factors SPECIFIED: Africans

\begin{tabular}{|c|c|c|c|c|}
\hline & \multicolumn{3}{|c|}{ Components } & \multirow{2}{*}{$\begin{array}{c}\text { Menon (2001) } \\
\text { and } \\
\text { Menon \& } \\
\text { Hartmann } \\
(2002)\end{array}$} \\
\hline & 1 & 2 & 3 & \\
\hline $\begin{array}{l}\text { 22. I can do my work } \\
\text { efficiently. }\end{array}$ & 0,789 & 0,148 & 0,070 & Competency \\
\hline $\begin{array}{l}\text { 21. Important responsibilities } \\
\text { are part of my job. }\end{array}$ & 0,768 & 0,139 & 0,168 & Perceived control \\
\hline $\begin{array}{l}\text { 23. I am keen on our doing well } \\
\text { as an organisation. }\end{array}$ & 0,753 & 0,207 & 0,190 & $\begin{array}{l}\text { Goal } \\
\text { internalisation }\end{array}$ \\
\hline $\begin{array}{l}\text { 13. I am enthusiastic about } \\
\text { the contribution my work } \\
\text { makes to the organisation. }\end{array}$ & 0,707 & 0,324 & 0,192 & $\begin{array}{l}\text { Goal } \\
\text { internalisation }\end{array}$ \\
\hline $\begin{array}{l}\text { 12. I have the capabilities } \\
\text { required to do my job well. }\end{array}$ & 0,705 & 0,337 & 0,068 & Competency \\
\hline $\begin{array}{l}\text { 17. I can handle the challenges } \\
\text { I face at work. }\end{array}$ & 0,676 & 0,240 & 0,184 & Competency \\
\hline $\begin{array}{l}\text { 18. I am inspired by what we } \\
\text { are trying to achieve as an } \\
\text { organisation. }\end{array}$ & 0,624 & 0,290 & 0,302 & $\begin{array}{l}\text { Goal } \\
\text { internalisation }\end{array}$ \\
\hline $\begin{array}{l}\text { 11. I have the authority to work } \\
\text { effectively. }\end{array}$ & 0,480 & 0,302 & 0,446 & Perceived control \\
\hline $\begin{array}{l}\text { 3. I am inspired by the goals } \\
\text { of the organisation. }\end{array}$ & 0,255 & 0,742 & 0,190 & $\begin{array}{l}\text { Goal } \\
\text { internalisation }\end{array}$ \\
\hline $\begin{array}{l}\text { 2. I have the skills and abilities } \\
\text { to do my job well. }\end{array}$ & 0,350 & 0,696 & 0,074 & Competency \\
\hline $\begin{array}{l}\text { 1. I can influence the way } \\
\text { work is done in my unit/ } \\
\text { base/ship. }\end{array}$ & 0,096 & 0,689 & 0,212 & Perceived control \\
\hline $\begin{array}{l}\text { 8. I am enthusiastic about } \\
\text { working towards the } \\
\text { organisation's objectives. }\end{array}$ & 0,502 & 0,551 & 0,189 & $\begin{array}{l}\text { Goal } \\
\text { internalisation }\end{array}$ \\
\hline $\begin{array}{l}\text { 7. I have the competence to } \\
\text { work effectively. }\end{array}$ & 0,359 & 0,515 & 0,346 & Competency \\
\hline $\begin{array}{l}\text { 6, I have the authority to } \\
\text { make decisions at work. }\end{array}$ & 0,055 & 0,309 & 0,771 & Perceived control \\
\hline $\begin{array}{l}\text { 16, I can influence decisions } \\
\text { taken in my department. }\end{array}$ & 0,278 & 0,003 & 0,739 & Perceived control \\
\hline
\end{tabular}

Extraction Method: Principal Component Analysis.

Rotation Method: Varimax with Kaiser Normalization.

Rotation converged in 5 iterations.

The above table indicates that the factor structure for the African group does not match that reflected in international research.

TABLE 4

FACTOR ANALYSIS RESULTS FOR THREE FACTORS SPECIFIED: Coloureds AND Asians

\begin{tabular}{|c|c|c|c|c|}
\hline & \multicolumn{3}{|c|}{ Components } & \multirow{2}{*}{$\begin{array}{l}\text { Menon } \\
(2001) \text { and } \\
\text { Menon \& } \\
\text { Hartman } \\
(2002)\end{array}$} \\
\hline & 1 & 2 & 3 & \\
\hline 22. I can do my work efficiently. & 0,812 & 0,233 & 0,087 & Competency \\
\hline $\begin{array}{l}\text { 21. Important responsibilities are } \\
\text { part of my job. }\end{array}$ & 0,739 & 0,038 & 0,265 & $\begin{array}{l}\text { Perceived } \\
\text { control }\end{array}$ \\
\hline $\begin{array}{l}\text { 23. I am keen on our doing well as } \\
\text { an organisation. }\end{array}$ & 0,668 & 0,309 & 0,155 & $\begin{array}{l}\text { Goal } \\
\text { internalisation }\end{array}$ \\
\hline $\begin{array}{l}\text { 12. I have the capabilities required } \\
\text { to do my job well. }\end{array}$ & 0,633 & 0,346 & 0,140 & Competency \\
\hline $\begin{array}{l}\text { 11. I have the authority to work } \\
\text { effectively. }\end{array}$ & 0,625 & 0,016 & 0,393 & $\begin{array}{l}\text { Perceived } \\
\text { control }\end{array}$ \\
\hline $\begin{array}{l}\text { 18. I am inspired by what we } \\
\text { are trying to achieve as an } \\
\text { organisation. }\end{array}$ & 0,589 & 0,395 & 0,206 & $\begin{array}{l}\text { Goal } \\
\text { internalisation }\end{array}$ \\
\hline $\begin{array}{l}\text { 13. I am enthusiastic about the } \\
\text { contribution my work makes to } \\
\text { the organisation. }\end{array}$ & 0,582 & 0,375 & 0,235 & $\begin{array}{l}\text { Goal } \\
\text { internalisation }\end{array}$ \\
\hline
\end{tabular}

17. I can handle the challenges I $\quad \mathbf{0 , 5 7 7} \quad 0,341 \quad 0,144 \quad$ Competency face at work.

2. I have the skills and abilities to $\quad 0,278 \quad \mathbf{0 , 7 9 0} \quad 0,114$ Competency do my job well.

7. I have the competence to work $\quad 0,186 \quad \mathbf{0 , 6 7 3} 0,196$ Competency effectively.

3. I am inspired by the goals of the $0,264 \quad 0,618 \quad 0,221$ Goal organisation. internalisation

8. I am enthusiastic about working $\quad 0,343 \quad \mathbf{0 , 5 9 4} \quad 0,288$ Goal towards the organisation's internalisation objectives.

16, I can influence decisions taken $\quad 0,202 \quad 0,078 \quad 0,756 \quad$ Perceived in my department.

6. I have the authority to make $\quad 0,160 \quad 0,137 \quad 0,724 \quad$ Perceived decisions at work.

control

1. I can influence the way work is $0,023 \quad 0,519 \quad 0,593$ Perceived done in my unit/base/ship. control

Extraction Method: Principal Component Analysis.

Rotation Method: Varimax with Kaiser Normalization.

Rotation converged in 7 iterations.

The above table indicates that the factor structure for the Asian and Coloured group does not reflect the same structure as that found in international research.

TABle 5

FACTOR ANALYSIS RESULTS FOR THREE FACTORS SPECIFIED: WHITES

\begin{tabular}{|c|c|c|c|c|}
\hline & \multicolumn{3}{|c|}{ Components } & \multirow{2}{*}{$\begin{array}{l}\text { Menon (2001); } \\
\text { Menon \& } \\
\text { Hartman } \\
(2002)\end{array}$} \\
\hline & 1 & 2 & 3 & \\
\hline $\begin{array}{l}\text { 12. I have the capabilities required } \\
\text { to do my job well. }\end{array}$ & 0,809 & 0,098 & 0,139 & Competency \\
\hline $\begin{array}{l}\text { 7. I have the competence to work } \\
\text { effectively. }\end{array}$ & 0,778 & 0,197 & 0,142 & Competency \\
\hline 22. I can do my work efficiently. & 0,756 & 0,322 & 0,123 & Competency \\
\hline $\begin{array}{l}\text { 2. I have the skills and abilities to } \\
\text { do my job well. }\end{array}$ & 0,732 & 0,049 & 0,166 & Competency \\
\hline $\begin{array}{l}\text { 17. I can handle the challenges I } \\
\text { face at work. }\end{array}$ & 0,656 & 0,308 & 0,195 & Competency \\
\hline $\begin{array}{l}\text { 21. Important responsibilities are } \\
\text { part of my job. }\end{array}$ & 0,537 & 0,326 & 0,341 & $\begin{array}{l}\text { Perceived } \\
\text { control }\end{array}$ \\
\hline $\begin{array}{l}\text { 18. I am inspired by what we } \\
\text { are trying to achieve as } \\
\text { rganisation. }\end{array}$ & 0,139 & 0,832 & 0,194 & $\begin{array}{l}\text { Goal } \\
\text { internalisation }\end{array}$ \\
\hline $\begin{array}{l}\text { 8. I am enthusiastic about } \\
\text { working towards the } \\
\text { organisation's objectives. }\end{array}$ & 0,292 & 0,797 & 0,114 & $\begin{array}{l}\text { Goal } \\
\text { internalisation }\end{array}$ \\
\hline $\begin{array}{l}\text { 3. I am inspired by the goals of } \\
\text { the organisation. }\end{array}$ & 0,016 & 0,711 & 0,388 & $\begin{array}{l}\text { Goal } \\
\text { internalisation }\end{array}$ \\
\hline $\begin{array}{l}\text { 23. I am keen on our doing well } \\
\text { as an organisation. }\end{array}$ & 0,346 & 0,709 & 0,046 & $\begin{array}{l}\text { Goal } \\
\text { internalisation }\end{array}$ \\
\hline $\begin{array}{l}\text { 13. I am enthusiastic about the } \\
\text { contribution my work makes } \\
\text { to the organisation. }\end{array}$ & 0,483 & 0,580 & 0,246 & $\begin{array}{l}\text { Goal } \\
\text { internalisation }\end{array}$ \\
\hline $\begin{array}{l}\text { 6, I have the authority to make } \\
\text { decisions at work. }\end{array}$ & 0,147 & 0,084 & 0,812 & $\begin{array}{l}\text { Perceived } \\
\text { control }\end{array}$ \\
\hline $\begin{array}{l}\text { 16, I can influence decisions } \\
\text { taken in my department. }\end{array}$ & 0,177 & 0,091 & 0,788 & $\begin{array}{l}\text { Perceived } \\
\text { control }\end{array}$ \\
\hline $\begin{array}{l}\text { 1. I can influence the way work } \\
\text { is done in my unit/base/ship. }\end{array}$ & 0,134 & 0,314 & 0,683 & $\begin{array}{l}\text { Perceived } \\
\text { control }\end{array}$ \\
\hline $\begin{array}{l}\text { 11. I have the authority to work } \\
\text { effectively. }\end{array}$ & 0,371 & 0,267 & 0,611 & $\begin{array}{l}\text { Perceived } \\
\text { control }\end{array}$ \\
\hline
\end{tabular}

Extraction Method: Principal Component Analysis.

Rotation Method: Varimax with Kaiser Normalization.

Rotation converged in 5 iterations.

For this group the factors identified coincided with those identified in the three international studies. Just one item of the perceived control factor loaded on the competency factor as defined by Menon(2001). 


\section{Reliability coefficients}

Reliability coefficient were calculated for the total scale and also for each factor separately, as Streiner (2003, p99) stated that "you cannot trust that published estimates of alpha apply in all situations", and the SANDF group is different from the groups in published reports. The results are reflected in Table 6.

TABLE 6

RELIABILITY COEFFICIENTS

\begin{tabular}{lcccc}
\hline Group & $\begin{array}{c}\text { Alpha } \\
\text { Total Scale }\end{array}$ & $\begin{array}{c}\text { Alpha } \\
\text { Factor 1 }\end{array}$ & $\begin{array}{c}\text { Alpha } \\
\text { Factor 2 }\end{array}$ & $\begin{array}{c}\text { Alpha } \\
\text { Factor 3 }\end{array}$ \\
\hline Total group & 0,904 & 0,891 & 0,778 & 0,566 \\
& $(15$ items $)$ & $(8$ items $)$ & $(5$ items $)$ & $(2$ items $)$ \\
Africans & 0,907 & 0,897 & 0,789 & 0,515 \\
& $(15$ items $)$ & $(8$ items $)$ & $(5$ items $)$ & $(2$ items $)$ \\
Asians and & 0,877 & 0,596 & 0,742 & 0,648 \\
Coloureds & $(15$ items $)$ & $(8$ items $)$ & $(4$ items $)$ & $(3$ items $)$ \\
Whites & 0,901 & 0,864 & 0,856 & 0,786 \\
& $(15$ items $)$ & $(6$ items $)$ & $(5$ items $)$ & $(4$ items $)$ \\
\hline
\end{tabular}

From Table 6 it is clear that the three-factor structures rendered very high internal consistencies for the total scale, but that factor 3 for the African group and factor 1 for the Asian and Coloured group showed unsatisfactory reliability.

Next the inter-correlations between the three subscales are reported in Table 7.

TABLE 7

SUB-SCALE INTER-CORRELATIONS

\begin{tabular}{|c|c|c|c|c|}
\hline \multirow{2}{*}{$\begin{array}{l}\text { Total group } \\
\text { Perceived control }\end{array}$} & \multicolumn{2}{|c|}{ Mean and SD } & \multirow{2}{*}{$\begin{array}{c}\text { Perceived } \\
\text { control }\end{array}$} & \multirow{2}{*}{$\begin{array}{c}\begin{array}{c}\text { Perceived } \\
\text { competency }\end{array} \\
\end{array}$} \\
\hline & 5,06 & 1,28 & & \\
\hline Perceived competency & 5,98 & 1,14 & 0,645 * * & \\
\hline Goal internalisation & 5,56 & 1,26 & 0,659 * * & 0,730 * * \\
\hline \multicolumn{5}{|l|}{ Africans } \\
\hline Perceived control & 4,84 & 1,35 & & \\
\hline Perceived competency & 5,79 & 1,26 & $0,676^{* *}$ & \\
\hline Goal internalisation & 5,52 & 1,35 & 0,709 ** & $0,799 * *$ \\
\hline \multicolumn{5}{|l|}{ Asians and Coloureds } \\
\hline Perceived control & 5,40 & 1,10 & & \\
\hline Perceived competency & 6,33 & 0.80 & 0,501 * * & \\
\hline Goal internalisation & 5,89 & 1,00 & 0,601 * * & $0,682 * *$ \\
\hline \multicolumn{5}{|l|}{ Whites } \\
\hline Perceived control & 5,35 & 1,13 & & \\
\hline Perceived competency & 6,21 & 1,00 & 0,540 * * & \\
\hline Goal internalisation & 5,45 & 1,00 & 0,573 * * & $0,558 * *$ \\
\hline
\end{tabular}

** Correlation is significant at the 0,01 level (2-tailed).

From Table 7 it is clear that there were high inter-correlations between the three sub-scales, which insinuate that there might rather be one underlying empowerment factor than three distinct components.

\section{DISCUSSION}

The main findings of the study seem to indicate that the research could not confirm the factor structures obtained in Western countries (Menon, 2001; Menon \& Hartmann, 2002; Dimitriades, 2005). The South African data initially yielded a two factor structure. A forced three-factor structure rendered acceptable alpha coefficients, but did not resemble the perceived control, competency and goal internalisation components as was theoretically expected, except for the third factor comprising two items that belonged to the theoretically hypothesised perceived control scale.
The findings further indicate that ethnic group influences the factor structure of the scale. When the factor analyses results for the total sample and the African group are compared it becomes evident that exactly the same items load on the three respective factors. This is probably due to the fact that more than $60 \%$ of the total group were Africans. Furthermore, when the factor structures of the total group and the Asian and Coloured group are compared, exactly the same items load on factor 1 . Similarly, factors 2 and 3 for the Asian and Coloured group are also exactly the same as those for the total group except for one item that shows a cross-loading on factors 2 and 3 , which did not occur in the total group's analysis. On the other hand the results from the White group resemble the international factor structure (Menon, 2001; Menon \& Hartmann,2002; Dimitriades, 2005) except for one item ("important responsibilities are part of my job"), which loads on the goal internalisation factor and not on the perceived control factor as expected. One item, ("I am enthusiastic about the contribution my work makes to the organisation") shows a cross-loading on the competency factor.

The reliability coefficients differ for the different cultural groups, ranging from 0,515 for factor 3 (African group) to 0,897 for factor 1 (African group). The Whites' coefficients were more evenly spread $(0,786$ to 0,864$)$. Menon and Hartmann reported alpha reliabilities of higher than 0,81 for the Australian data, while Dimitriades (2005) observed acceptable reliabilities higher than 0,60. For the South African data the forced three-factor structures rendered internal consistencies above 0,90 for the total scale, but factor 3 for the African group and factor 1 for the Asian and Coloured group showed unsatisfactory reliability. It thus seems as if the forced factor approach had a negative influence on the internal consistency of the factors. Furthermore, it might also be that non-white South African respondents, contrary to the white respondents, interpret the items as reflecting one single concept and not as three different ways to be empowered. This notion is supported by the very high correlations between the sub-scales (table 7), which is also not in accordance with international reportings where very low inter-correlations were established (Menon, 2001; Menon \& Hartmann, 2002; Dimitriades, 2005). The alphas above 0,90 for the total scale might "reflect unnecessary duplication of content across items and point more to redundancy than to homogeneity among the items" (Streiner, 2003, p102). It might therefore be worthwhile to consider using Menon's (2001) nine item version of the scale rather than the 15 item full scale.

When the average scores for the three empowerment components are compared to international findings, the South African participants seem to feel equally and possibly even more empowered than the international respondents. In actual fact, all groups' mean scores were higher than those reported by Menon (2001) and Menon and Hartmann (2002). Although the aim of this study was not to evaluate the success of the transformational leadership programme that was introduced in the SANDF as a means to empower its employees to face the challenges of the new South Africa after 1994, the above finding seems to suggest that the programme is bearing fruit, as SANDF employees indeed feel psychologically empowered. The forced adaptation to a more ambiguous environment due to the societal changes and challenges of the dispensation after 1994 was thus for the best of the organisation.

However, an alternative explanation for the higher average empowerment scores of South African respondents might be that they were inclined to mark responses towards the higher end of the scale. If this were the case, the above argument would of course be nullified. 


\section{CONCLUSION}

If it is accepted that the internal construct validity of a scale can be judged on how well it taps into the different dimensions suggested by relevant theory, the Menon Scale (2001) seemingly has a lower internal construct validity for non-white respondents than for their white counterparts, which might be an indication that the scale is, to a certain extent, culturally bound when applied in a heterogeneous institution such as the SANDF. This finding supports Matsumoto and Juang's (2004) statement that different cultural groups have different perceptions, and that these differences could influence the interpretation of psychological constructs. It follows that the items of the instrument should be scrutinised to determine whether the fact that the questions were in English could have had a negative influence in a setting where English is not the first language of the majority of the participants. However, even if this is confirmed, it will just accentuate a general problem of the South African society where English is by default the language of the work environment.

\section{Limitations and suggestions for further research}

From the findings of this study it is concluded that the scale in its present format cannot be generalised to all the different population groups in the SANDF. The findings accentuate the need for further investigation with regard to the factorial invariance of the scale across different cultural groups, as it seems as if Menon's model fit the South African data slightly better for the white participants in this study than for their non-white counterparts. The scale thus needs to be revised and every item scrutinised to determine whether it could have been differently interpreted by the non-white participants. This approach can be enhanced through a qualitative study where interviews are used to determine how the different groups exactly understand the concept of empowerment.

\section{REFERENCES}

Avolio, B.J., Zhu, W., Koh, W. \& Bhatia, P. (2004). Transformational leadership and organizational commitment: mediating role of psychological empowerment and moderationg role of structural distance. Journal of Organizational Behavior, 25, (951-968).

Boudrias, J-S., Gaudreau, P. \& Laschinger, H.K.S., (2004). Testing the structure of psychological empowerment: Does gender make a difference? Educational and Psychological Measurement, 64(5), 861-877.
Conger, J.A. \& Kanungo, R.N. (1988). The empowerment process: Integrating theory and practice. Academy of Management Review, 13, 471-482.

Dimitriades, Z.S. (2005). Employee empowerment in the Greek context. International Journal of Manpower, 26(1), 80-92.

Foxcroft, C.D. \& Roodt, G. (Eds) (2001). An introduction to psychological assessment in the South African context. Cape Town: Oxford University Press Southern Africa.

Khosa, M.M. (2001). Empowerment and transformation in South Africa In M.M. Khosa (ed), Empowerment through economic transformation. Durban: African Millenium Press, pp 1-20.

Kotze, E., Khashane, E. \& Mthembu, O. (In press). Psychological empowerment in the military: The role of gender and race. Journal of Public Administration.

Kraimer, M.L., Seibert, S.E. \& Liden, R.C. (1999). Psychological empowerment as a multidimensional construct: A test of construct validity. Educational and Psychological Measurement, 59(1), 127-142.

Laschinger, H.K.S., Finegan, J.E., Shamian, J. \& Wilk, P. (2004). A logitudinal analysis of the impact of workplace empowerment on work satisfaction. Journal of Organizational Behavior, 25, 527-545,

Matsumoto. D. \& Juang, L. (2004) ( $3^{\text {rd }}$ ed). Culture and psychology: People around the world. Belmont: Wadsworth.

Menon, S.T. (2001). Employee empowerment: An integrative psychological approach. Applied Psychology: An International Review, 50(1), 153-180.

Menon, S.T. \& Hartmann, L.C. (2002). Generalizability of Menon's empowerment scale. Replication and extension with Australian data. International Journal of Cross Cultural Management, 2(2), 137-153.

Menon, S.T. \& Kotze, E. (2004). Psychological empowerment as indicator of racial and gender integration in the South African military. A preliminary study. Paper presented at the $9^{\text {th }}$ Bi-Annual Conference of the International Society for the Study of Work and Organisational Values, New Orleans, 2-4 August 2004.

Spreitzer, G.M. (1995). Psychological empowerment in the workplace: Construct definition, measurement, and validation. Academy of Management Journal, 38, 1442-1465,

Spreitzer, G.M. (1996). Social structural characteristics of psychological empowerment. Academy of Management Journal, 39(2), 483-504.

Streiner, D.L. (2003). Starting at the beginning: An introduction to coefficient alpha and internal consistency. Journal of Personality Assessment, 80(1), 99-103.

Thomas, K.W. \& Velthouse, B.A. (1990). Cognitive elements of empowerment: An "interpretive" model of intrinsic task motivation. Academy of Management Review, 15, 666-681. 